\title{
James Hutton's Theory of the Earth..., 1785
}

In Edinburgh on 7 March 1785, Theory of the Earth; or an Investigation of the Laws observable in the Composition, Dissolution and Restoration of the Land upon the Globe announced one of the greatest discoveries in the history of Western science. The first part of the paper was presented to the Royal Society of Edinburgh by a Fellow of the Royal College of Physicians of Edinburgh, Joseph Black. Black had made a crucial contribution but otherwise the study was the work of James Hutton, MD who presented the second part of the report a month later on 4 April 1785. The full text can be found in the first (1788) volume of the Transactions of the Royal Society of Edinburgh which is among the RCPE's great collection of medical and scientific journals. The text ends with the momentous statement that time has 'no vestige of a beginning, no prospect of an end.'

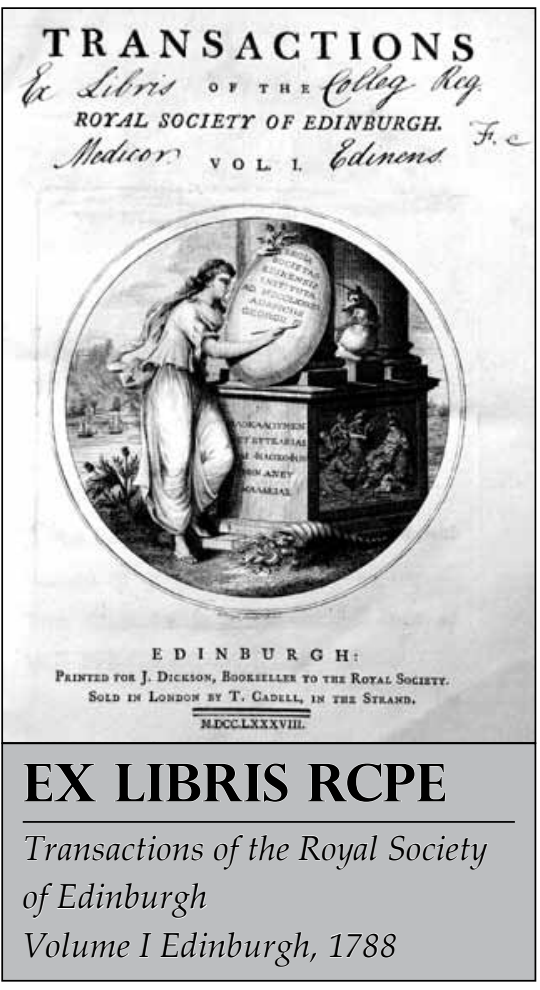

After returning to Edinburgh, Hutton did not practise medicine. He set up a successful business in Edinburgh manufacturing sal ammoniac by a method that he had invented himself; his product found a ready market in the production of iron. In 1754, he left the business in the hands of his partner, John Davie, and devoted his time to the improvement of the two farms that he had inherited from his father. As his prime interest was in improving the quality of the soil he studied the characteristics of the soil on farms across Britain and the Netherlands.* He also studied the local rock formations since, as he explained, 'soil is nothing but the materials collected from the destruction of the solid land.' It was these observations continued over some thirty years that led to the formulation of his Theory of the Earth.

For many years it had been accepted throughout the English-speaking world that the universe was less than 6,000 years old. In 1658, in his Annals of the World, Archbishop James Ussher, Primate of All Ireland, had written that 'the beginning of time fell upon the entrance of the night preceding the twenty-third day of October in the year 4004 [BC].' This date had been accepted by the Church of England and had been given the authority of inclusion in the text of the English Bible. But after an investigation lasting many years Hutton proved that Ussher was wrong.

James Hutton was born in Edinburgh on 3 June 1726. He was educated at The Royal High School and at the University of Edinburgh where he was taught mathematics by Sir Isaac Newton's protégé, Colin Maclaurin. At the same time Hutton was introduced to the new science of chemistry. In 1743 he was apprenticed by his father to a lawyer, but Hutton had become greatly attracted by the possibilities of chemistry and not at all by the prospect of a career in the law. In 1744 he enrolled as a medical student at Edinburgh, not with any intention of practising medicine but because the study of chemistry was then only taught at Edinburgh as part of the curriculum required for the MD degree. In 1747, he left Edinburgh to continue his study of chemistry at the Sorbonne in Paris. After two productive years there he made his way home, staying long enough in Leiden to take the MD degree.

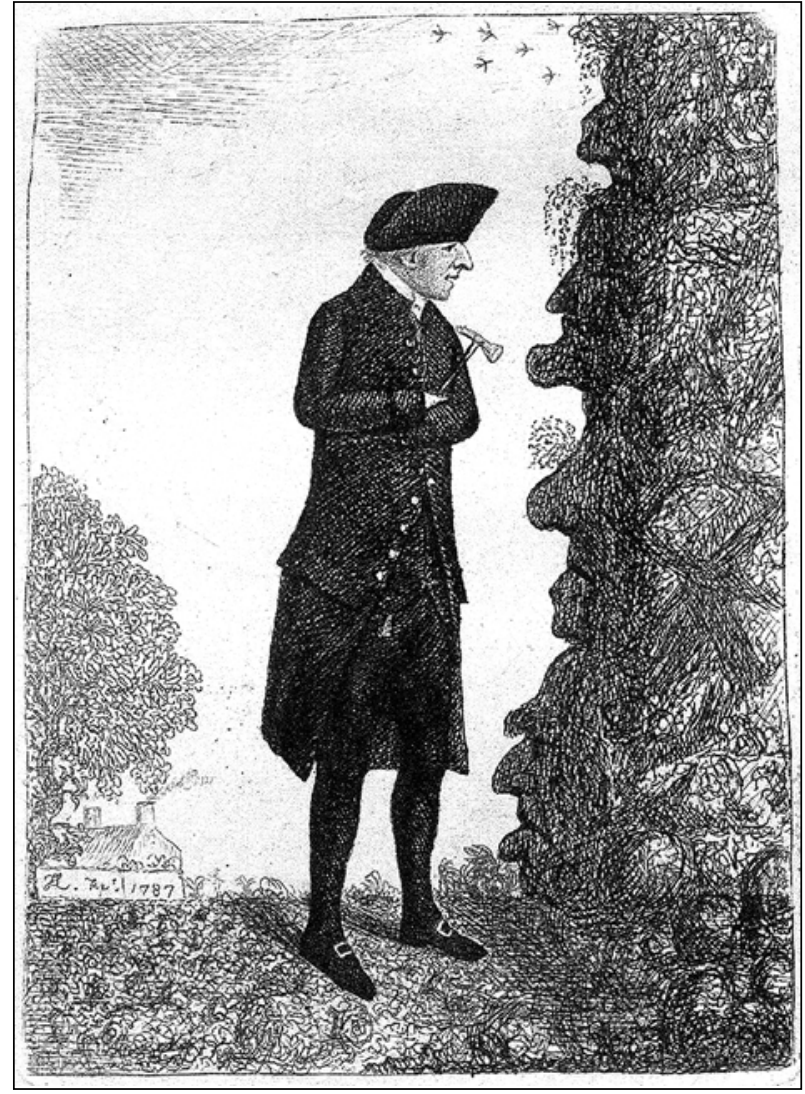

FIGURE I Portrait of James Hutton by John Kay and dated 1787 . 
X. THEORY of tbe EARTH; or an INVESTIGATION of tbe Lawes obfervable in tbe Compofition, Difolution, and Reforation of Land upon the Globe. By FAMES HUTTON, M. D. F. R. S. Edin. and Member of the Royal Academy of Agriculture at PARIS.

[Read Marcb 7. and April 4. 1785.]

$$
\text { P A R T. I. }
$$

Propeat of the Subjea to be treated of.

W ${ }^{\text {H EN we trace the parts of which this terreftrial fyftem }}$ is compofed, and when we view the general connection of thofe feveral parts, the whole prefents a machine of a peculiar conftruction by which it is adapted to a certain end. We perceive a fabric, erected in wifdom, to obtain a purpofe worthy of the power that is apparent in the production of it.

We know little of the earth's internal parts, or of the materials which compofe it at any confiderable depth below the furface. But upon the furface of this globe, the more inert matter is replenifhed with plants, and with animal and intellectual beings.

WHERE fo many living creatures are to ply their refpective powers, in purfuing the end for which they were intended, we are not to look for nature in a quiefcent ftate; matter itfelf muft be in motion, and the fcenes of life a continued or repeated feries of agitations and events.

Tuis globe of the earth is a habitable world; and on its fitnefs for this purpofe, our fenfe of wifdom in its formation D d muit

FIGURE 2 The first page of Hutton's paper read to the Royal Society of Edinburgh in March and April 1785.

The text begins:

When we trace the parts of which this terrestrial system is compounded, and when we view the general connection of those several parts the whole presents a machine of a peculiar construction by which it is adapted to a certain end. We perceive a fabric, erected in wisdom, to obtain a purpose worthy of the power that is apparent in the production of it."

In the first part of this system:

Our fertile plains are formed from the ruins of the mountains; and those travelling materials are pursued by moving water and propelled along the inclined surface of the earth. These movable materials, delivered into the sea cannot for a continuance rest upon the shore for by the agitation of the winds, the tides and currents every movable thing is carried towards the unfathomable regions of the ocean and propelled into the sea.'

In his theory Hutton envisaged that the debris of the mountains is reconstituted into rock on the floor of the sea before being returned to the surface to replace the eroded mountains. As evidence, he points out that:
There are few beds of marble or limestone in which there may not be found some of those objects which indicate the marine origin of the mass. If, for example, in a mass of marble taken from a quarry upon the top of the Alps or the Andes there shall be found one cockle shell or piece of coral it must be concluded that this bed of stone must have been originally at the bottom of the sea as much as another bed which is evidently composed almost altogether of cockle shells or coral.'

At first Hutton had no clear idea of how that reconstitution of the debris was accomplished at the bottom of the sea. However, on evidence provided by Joseph Black,' he understood that the debris committed to the sea bed is melted and coalesced by the extreme subterranean heat. And from his observations of the orientation of the rock strata at innumerable sites across Britain he believed it 'unquestionable that what had been originally at the bottom of the sea is at present in the highest of our land elevated by the power of heat above the level of the present sea.'

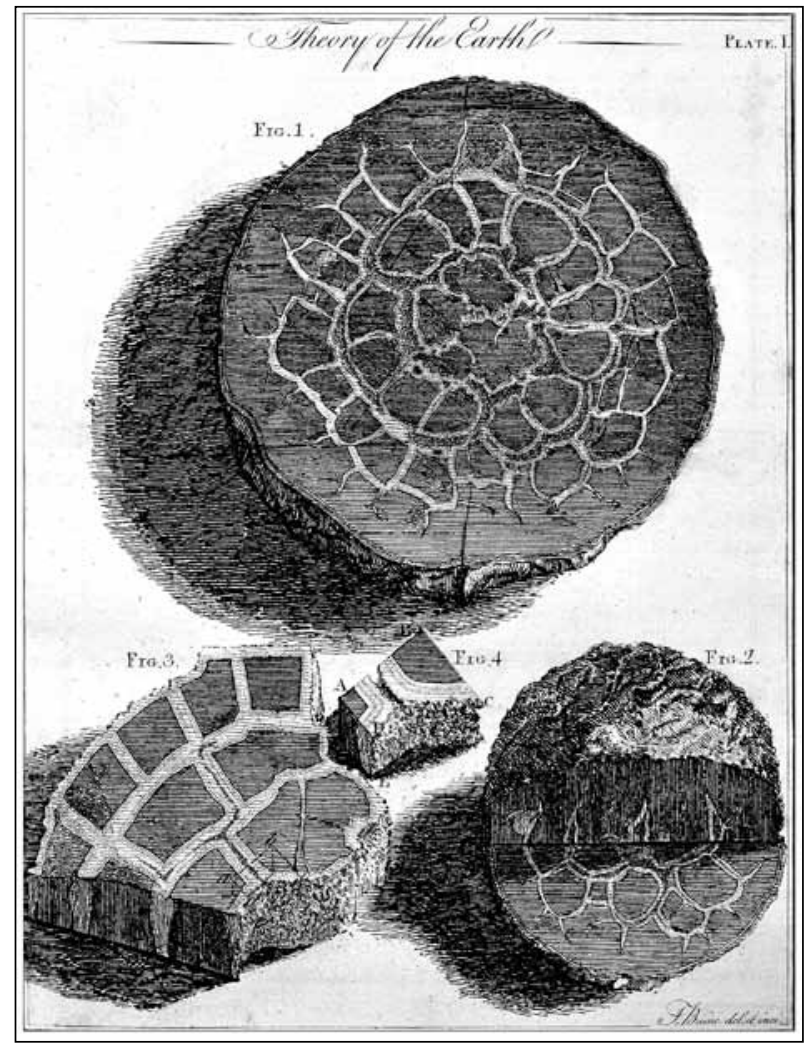

FIGURE 3 Plate I from Hutton's Theory of the Earth as published in the Transactions of the Royal Society of Edinburgh in 1788 showing (Figure I) a section of an ironstone septarium cut horizontally; (Figure 2) another septarium cut both horizontally and perpendicularly; (Figure3) part of a septarium in which the divisions are in straight lines; and (Figure 4) a portion of a septarium magnified to show the crystalline cavity of the septum. 


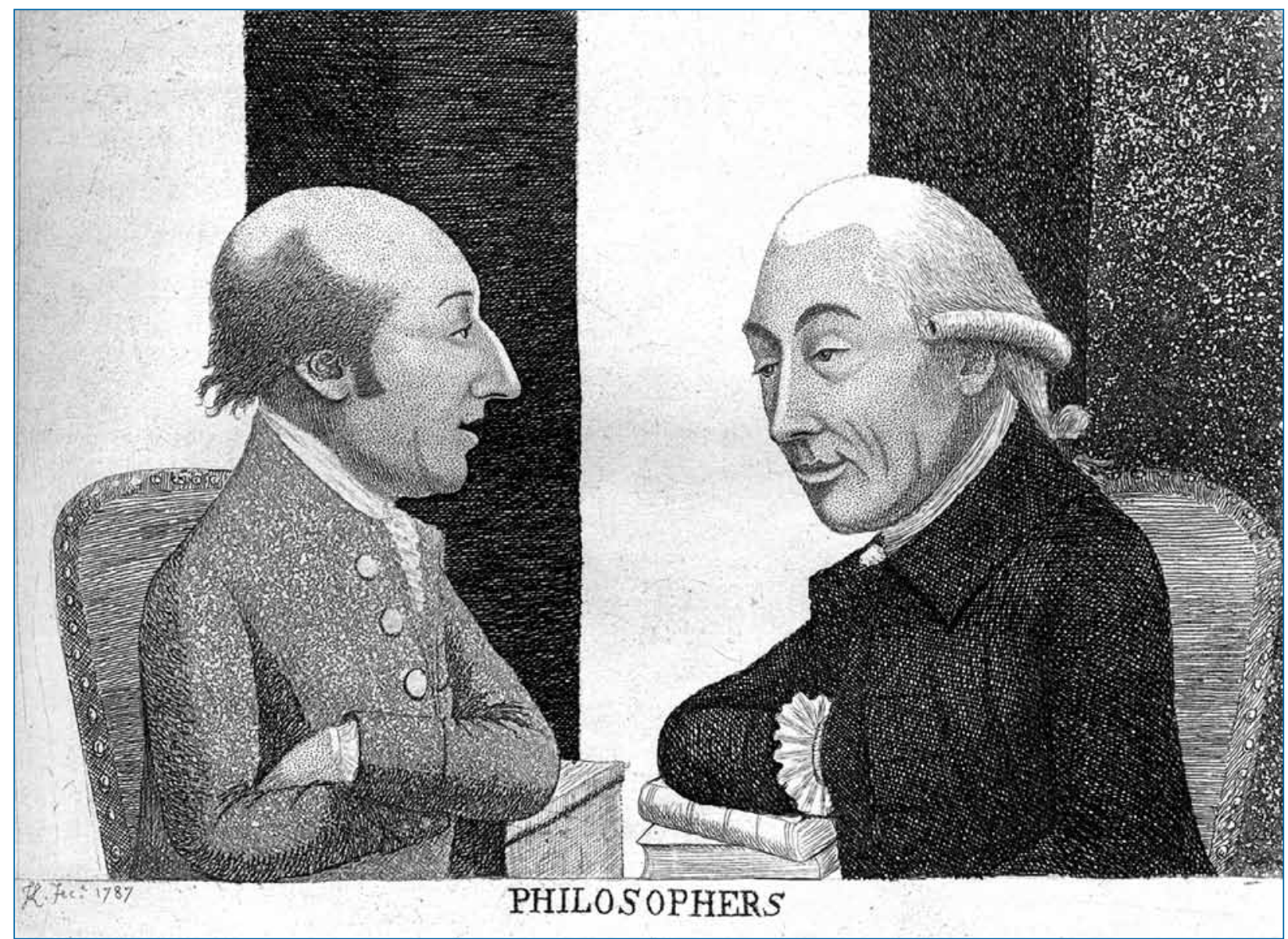

FIGURE 4 James Hutton and his chemistry teacher Joseph Black. Portrait by John Kay.

Hutton concluded that by this cyclical mechanism the surface of the earth was constantly being broken down and reshaped. Since these changes had proceeded so very slowly over the years that they were not discernible to the human eye even over many generations, the time they had occupied (and would continue to occupy) was infinite with 'no vestige of a beginning, no prospect of an end.'

Hutton did not publish his Theory of the Earth in book form until 1794. Unfortunately the book was so badly written that few succeeded in reading it. In 1802, five years after Hutton's death, John Playfair tried to explain the theory in his Illustrations of the Huttonian Theory of the Earth. However Hutton's theory did not become widely known until Sir Charles Lyell included it in his Principles of Geology in 1833.

\section{REFERENCE}

I Hutton J. Theory of the earth. Transactions of the Royal Society of Edinburgh 1788; I: 209-304.

\section{NOTE}

In 1758 Hutton wrote his Elements of Agriculture. The text was presented to the Royal Society of Edinburgh in 1797 but it was never published.

Morrice McCrae, College Historian, RCPE (email: drmmccrae@btinternet.com) 